Bernard Bruguerolle MD PhD, Xavier Roucoules MSc, Laurence Attolini MSc, Anne Marie Lorec Pharm D

\title{
Bupivacaine kinetics during hyperthermia in rats
}

The aim of this study was to document possible alterations of bupivacaine pharmacokinetic behaviour in rats during hyperthermia. Two groups of Wistar AF IOPS male rats (Group $A=$ normothermic controls, Group $B=$ hyperthermia-induced animals) received a single $20 \mathrm{mg} \cdot \mathrm{kg}^{-1}$ ip dose of bupivacaine. Two other groups (Group $C=$ normothermic controls without bupivacaine, Group $D=$ hyperthermia-induced animals without bupivacaine) received, under the same experimental conditions, an equivalent volume of saline. Hyperthermia-induced animals (Groups $B$ and D) were placed in a water-bath at $40^{\circ} \mathrm{C}$. Bupivacaine or saline were administered (Group $B$ and D) four hours after the beginning of the experiment and blood samples were obtained by retro-orbital sinus puncture $0.25,0.5,1,2$, 4 and $8 \mathrm{hr}$ after administration. Bupivacaine and its main metabolite, 2,6 desbutylbupivacaine ( $P P X)$ were assayed according to a gas liquid chromatographic method. The Cmax, Tmax, $t_{1 / 2}, \mathrm{Cl}, \mathrm{Vd}$ and $A U C$ were determined according to a two compartment open model. Our data have demonstrated a decrease in clearance of bupivacaine $\left(5.85 \pm 0.23 \mathrm{ml} \cdot \mathrm{hr}^{-1}\right.$ and $4.59 \pm 0.35 \mathrm{ml} \cdot \mathrm{hr}^{-1}$ for groups $A$ and $B$, respectively, $P<$ 0.05 , and, Tmax of PPX during hyperthermia $(0.24 \pm 0.03$ hr and $0.15 \pm 0.0 \mathrm{hr}$ for Groups $A$ and $B$, respectively, $P$ $<0.05$ ). In conclusion, hyperthermia induces a decrease in bupivacaine clearance in rats which may be of importance in clinical practice.

\section{Key words \\ ANAESTHETICS, LOCAL: bupivacaine; PHARMACOLOGY, PHARMACOKINETICS; HYPERTHERMIA.}

From the Medical Pharmacology Laboratory, Faculty of Medicine of Marseille, 27 Bd J. Moulin, F 13385 Marseille cedex 5, France.

This work was partially supported by a grant from "La

Fondation pour La Recherche Medicale."

Address correspondence to: Dr. B. Bruguerolle at the above address.

Accepted for publication 19th November, 1993.
Ce travail a eu pour but de rechercher l'existence éventuelle de modifications de la cinétique de la bupivacaïne chez le rat au cours d'une hyperthermie induite. Deux groupes de rats Wistar AF IOPS mâles (groupe $A=$ témoins normothermiques, groupe $B=$ animaux " hyperthermiques ") ont reçu une dose unique de $20 \mathrm{mg} \cdot \mathrm{kg}^{-1}$ ip de bupivacaïne. Deux autre groupes (groupe $C=$ témoins normothermiques ne recevant pas de bupivacaïne, groupe $D=$ animaux "hyperthermiques " ne recevant pas de bupivacaïne) ont été injectés dans les mêmes conditions avec du serum physiologique. Les animaux " hyperthermiques" (group B and D) ont été placés dans un bain-marie à $40^{\circ} \mathrm{C}$. La bupivacaïne ou le sérum physiologique ont été administrés (group $B$ and $D$ ) quatre heures après le début de l'expérimentation et le sang a été prélevé par ponction au sinus rétro-orbitaire $0,25,0,5,1,2,4$ et 8 heures après l'administration. La bupivacaüne et son principal métabolite, la 2,6 desbutylbupivacaïne (PPX), ont été déterminés par chromatographie gaz-liquide. Le Cmax, Tmax, $t_{1 / 2}, \mathrm{Cl}$, Vd et l'AUC ont été déterminés selon un modèle ouvert à deux compartiments. Les résultats obtenus ont montré une diminution statistiquement significative de la clairance de la bupivacaïne $(5,85$ $\pm 0.23 \mathrm{ml} \cdot \mathrm{h}^{-1}$ et $4,59 \pm 0,35 \mathrm{ml} \cdot \mathrm{h}^{-1}$ pour les groupes $A$ et $B$ respectivement, $P<0.05)$ et du Tmax de la $P P X(0,24$ $\pm 0,03$ h et $0,15 \pm 0,0 \mathrm{~h}$ pour les groupes $A$ et $B$ respectivement, $P<0.05)$ chez les animaux hyperthermiques. En conclusion, lhyperthermie entraine une diminution de la clairance de la bupivacaïne chez le rat qui si elle se vérifie chez lhomme, pourrait avoir des conséquences cliniques pratiques.

Many physiopathological or pharmacological factors which may influence the kinetic behaviour of one of the most commonly used local anaesthetic, bupivacaine, are under investigation in rodents in our laboratory. Among these, fever is known to modify some physiological variables involved in the pharmacokinetic behaviour of drugs;' ${ }^{1}$ febrile diseases may alter the kinetics of drugs such as aminopyrine, ${ }^{2}$ antipyrine, ${ }^{3}$ bisoprolol, ${ }^{4}$ nitrindipine, ${ }^{4}$ oxprenolol, ${ }^{5}$ phenytoin, ${ }^{6}$ pranoprofen, ${ }^{7}$ propranolol, ${ }^{8}$ quinine, ${ }^{9}$ theophylline. ${ }^{10}$

The influence of fever or hyperthermia on bupivacaine kinetics has not yet been documented to our knowledge. Thus, the aim of the present study was to document the possible alterations in pharmacokinetic behaviour of bu- 
pivacaine and its main metabolite, 2,6 desbutylbupivacaine (PPX), in rats during induced hyperthermia.

\section{Methods}

Adult male Wistar AF EOPS rats $(n=20$, mean weight $=280 \mathrm{~g}$ ) were housed before use, one to a cage for a minimum of three weeks under controlled relative humidity (50-55\%), temperature $25 \pm 1{ }^{\circ} \mathrm{C}$ and synchronisation by light-dark cycle $(06.00-18.00 \mathrm{hr}, 18.00-06.00$ hr) during the month of March with free access to food and water. In order to document the effect of hyperthermia on bupivacaine kinetics (a sufficient and durable increase in temperature was needed of at least $12 \mathrm{hr}$ ) we chose the water bath model. Briefly, rats were placed individually in a plastic cage, which was immersed in water at $40^{\circ} \mathrm{C}$ for four hours to obtain a stable temperature "plateau." Under these conditions the core temperature of the rats was maintained around $39^{\circ} \mathrm{C}$ for $12 \mathrm{hr}$. Two rats (in two different cages) were studied on the same day and two control (non-hyperthermic) rats were studied under the same experimental conditions. Four groups of five rats were studied as follows: Group $\mathrm{A}=$ normothermic controls receiving bupivacaine, Group B = hyperthermia-induced animals placed in the water bath for $12 \mathrm{hr}$ receiving bupivacaine, Group $\mathrm{C}=$ normothermic controls without bupivacaine (for measurement of basal temperature during the $12 \mathrm{hr}$ of the study) and Group D = hyperthermia-induced animals placed in the water bath for $12 \mathrm{hr}$ without bupivacaine (receiving the equivalent volume of salines). Rats of Groups B and D were placed in the water bath at 06.00 $\mathrm{hr}$ four hours before injection of bupivacaine (B) or the equivalent volume of saline (D). Then these animals were injected with a single $20 \mathrm{mg} \cdot \mathrm{kg}^{-1}$ ip dose of bupivacaine, $0.5 \%$, or saline at $10.00 \mathrm{hr}$. Rats of Groups A and C were maintained under the same normothermic conditions and were injected with a single $20 \mathrm{mg} \cdot \mathrm{kg}^{-1}$ ip dose of bupivacaine (A) or saline (C) at $10.00 \mathrm{hr}$. For Groups A and B, blood, $0.5 \mathrm{ml}$, was collected for each animal by puncture of the retro-orbital sinus $0,0.25,0.5$, $1,2,4$, and $8 \mathrm{hr}$ after administration. After each sample, $0.5 \mathrm{ml}$ of saline was injected ip to correct for blood loss. Blood was centrifuged and plasma was frozen immediately at $-20^{\circ} \mathrm{C}$ until assayed. In each of the four groups, rectal temperature was recorded each hour during $12 \mathrm{hr}$ from $10.00 \mathrm{hr}$ to $22.00 \mathrm{hr}$ with an electronic thermometer (model BAT, Bailey Instruments) and thermistor probe inserted rectally to a depth of $3 \mathrm{~cm}$ and maintained until a stable reading was obtained. Total serum concentrations of bupivacaine and its main metabolite, 2,6 desbutylbupivacaine (PPX), were determined by a specific gas liquid chromatographic method according to the technique of Bjork et al. "The sensitivity of the method was $5 \mathrm{ng} \cdot \mathrm{ml}^{-1}$

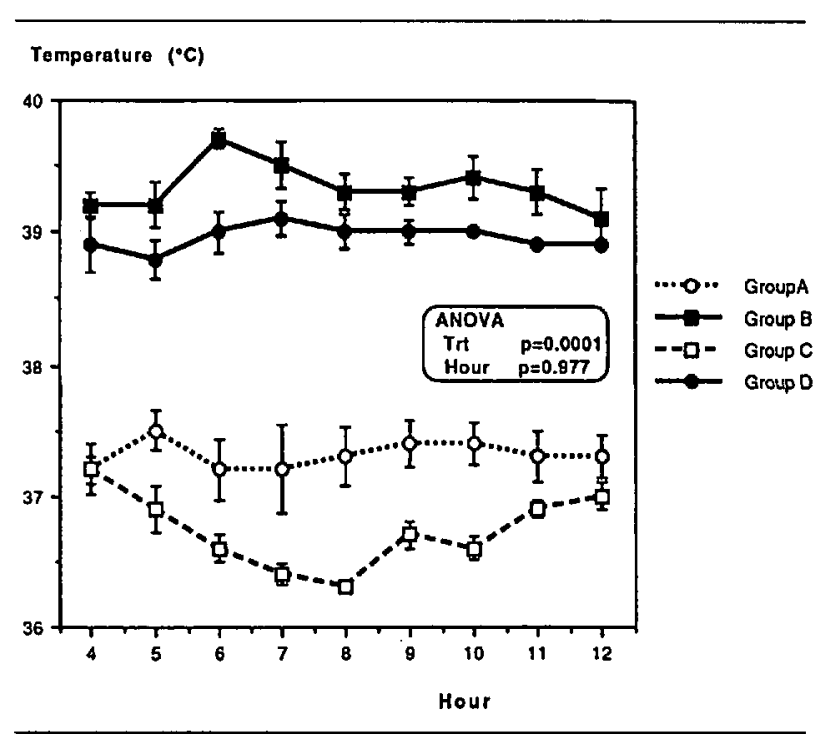

FIGURE 1 Mean \pm SEM temperature in controls and hyperthermic rats.

and the reproductibility was $<6 \%$. Serum bupivacaine concentrations were plotted against time and pharmacokinetic variables were determined assuming a twocompartment open model as previously described with a non-linear fitting method using a personal computer programme. ${ }^{12}$ The Cmax and the Tmax were derived directly from individual data. The $\beta$ phase elimination half-lives $\left(T_{1 / 2} \beta\right)$ and the area under the serum concentration curve $\left(\mathrm{AUC}_{0} \infty\right)$ were calculated. Total plasma clearance $(\mathrm{Cl})$ and total volume of distribution (Vd) were calculated according to the following equations: $\mathrm{Cl}=\mathrm{F}$ $X$ dose/AUC where $F$ is supposed to be equal to 1 and $\mathrm{Vd}=\mathrm{Cl} / \mathrm{Kel}$. For PPX, Cmax and Tmax were also derived directly from individual data and the ratio AUC of PPX on AUC of the parent drug, bupivacaine, was calculated. All data were summarized (means \pm SEM) and comparisons were performed by ANOVA.

\section{Results}

Mean \pm SEM temperatures measured each hour during the $12 \mathrm{hr}$ of the experiment are shown in Figure 1 for the four groups. The temperature of the animals in the water bath induced-hyperthermia groups was statistically different from that in controls. Also, bupivacaine induced an increase in temperature in hyperthermia-induced as well as in normothermic animals (i.e., Groups A and B compared to Groups $C$ and D).

Plasma concentrations of bupivacaine and PPX in control and hyperthermic rats are shown in Figure 2. The pharmacokinetic variables are listed in Tables I and II. Water bath-induced hyperthermia did not change the pharmacokinetic variables of bupivacaine and its main metabolite except for a decrease in the clearance of bu- 


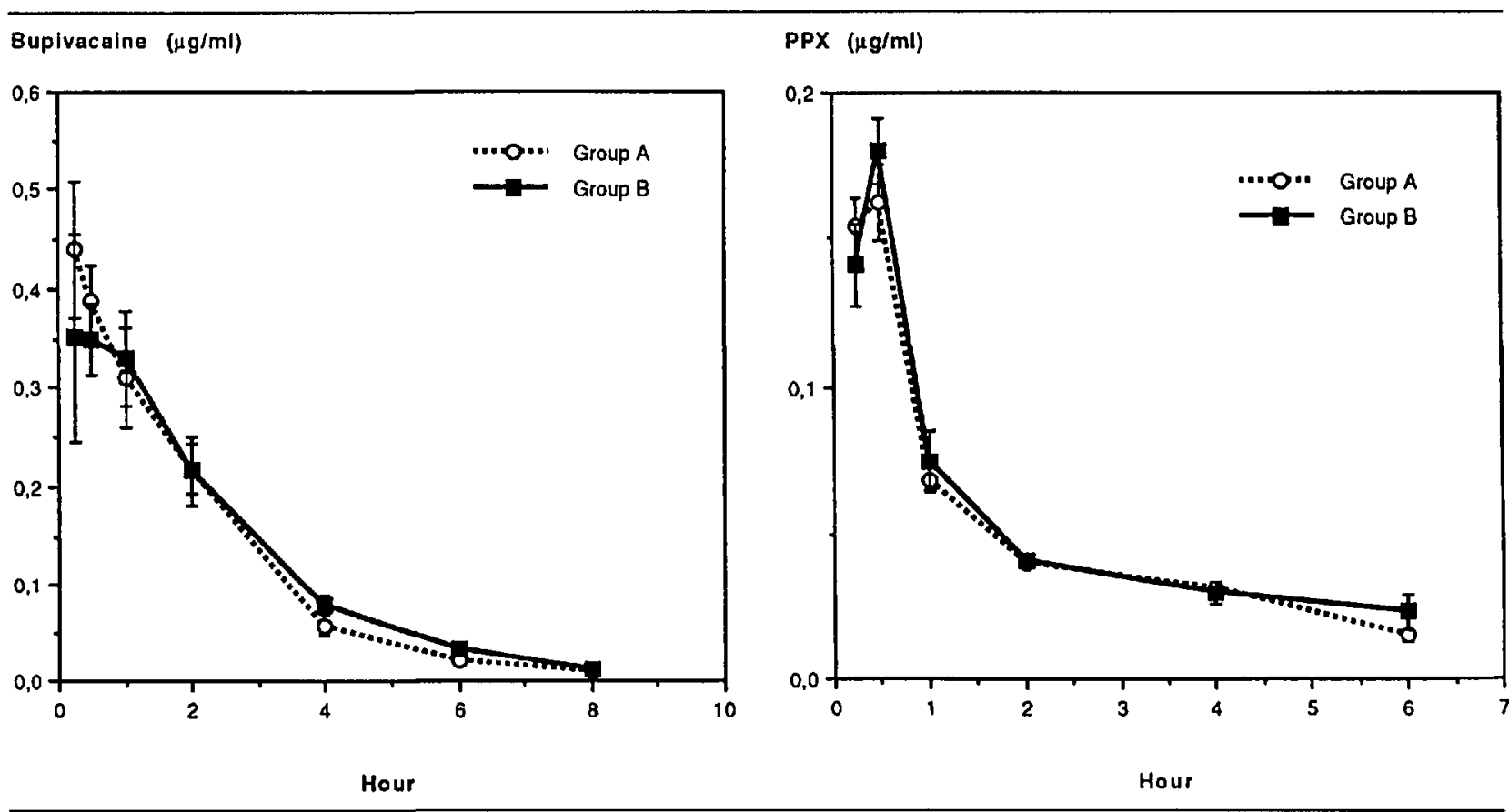

FIGURE 2 Bupivacaine (left) and PPX (right) plasma levels in control (A) and hyperthermic rats (B).

TABLE I Mean \pm SEM bupivacaine pharmacokinetic parameters in serum; Cmax: maximal concentration in serum ( $\mu \mathrm{g} \cdot \mathrm{ml}^{-1}$ ), Tmax: time to reach the $\mathrm{Cmax}(\mathrm{h}), \mathrm{T}_{1 / 2} \beta$ : $\beta$ elimination half-life $(\mathrm{h}), \mathrm{Cl}$ : total plasma clearance $(\mathrm{ml} \cdot \mathrm{hr})$, Vd: volume of distribution (ml) and AUC: area under concentration curve $\left(\mu \mathrm{g} \cdot \mathrm{ml} \cdot \mathrm{hr}^{-1}\right)$. Statistical comparison by ANOVA

\begin{tabular}{|c|c|c|c|c|c|c|}
\hline Group & $\begin{array}{l}C \max \\
\left(\mu g \cdot m \digamma^{-I}\right)\end{array}$ & $\begin{array}{l}\operatorname{Tmax} \\
(h)\end{array}$ & $\begin{array}{l}T_{1 / 2} \\
(h)\end{array}$ & $\begin{array}{l}C l \\
\left(\mathrm{ml} \cdot h^{-1}\right)\end{array}$ & $\begin{array}{l}V d \\
(m l)\end{array}$ & $\begin{array}{l}A U C \\
\left(\mu g \cdot m l \cdot h^{-1}\right)\end{array}$ \\
\hline Group A & $0.471 \pm 0.042$ & $0.180 \pm 0.030$ & $1.565 \pm 0.105$ & $5.854 \pm 0.230$ & $10.525 \pm 0.388$ & $0.982 \pm 0.142$ \\
\hline Group B & $0.519 \pm 0.071$ & $0.180 \pm 0.030$ & $1.519 \pm 0.000$ & $4.593 \pm 0.349$ & $10.105 \pm 0.733$ & $1.073 \pm 0.110$ \\
\hline ANOVA $F$ & 0.335 & NS & 0.193 & 9.076 & 0.256 & 0.259 \\
\hline $\mathbf{P}$ & 0.579 & NS & 0.672 & 0.016 & 0.626 & 0.624 \\
\hline
\end{tabular}

TABLE II Mean \pm SEM PPX pharmacokinetic parameters in serum; Cmax: maximal concentration in serum $\left(\mu \mathrm{g} \cdot \mathrm{ml}^{-1}\right)$, Tmax: time to reach the Cmax (h), AUC: area under concentration curve $\left(\mu \mathrm{g} \cdot \mathrm{ml}^{\prime} \cdot \mathrm{hr}^{-1}\right)$ and ratio AUC PPX/AUC bupivacaine. Statistical comparison by ANOVA.

\begin{tabular}{lllll}
\hline Group & $\begin{array}{l}\text { Cmax } \\
\left(\mu g \cdot m l^{-1}\right)\end{array}$ & $\begin{array}{l}\text { Tmax } \\
(\mathrm{h})\end{array}$ & $\begin{array}{l}\text { AUC } \\
\left(\mu \mathrm{g} \cdot \mathrm{ml} \cdot \mathrm{h}^{-1}\right)\end{array}$ & $\begin{array}{l}\text { AUC PPX/ } \\
\text { AUC bupivacaine }\end{array}$ \\
\hline Group A & $0.175 \pm 0.007$ & $0.240 \pm 0.034$ & $0.287 \pm 0.009$ & $0.322 \pm 0.054$ \\
Group B & $0.180 \pm 0.011$ & $0.150 \pm 0.000$ & $0.303 \pm 0.010$ & $0.296 \pm 0.041$ \\
ANOVA F & 0.156 & 6.00 & 1.313 & 0.155 \\
P & 0.704 & 0.04 & 0.285 & 0.704 \\
\hline
\end{tabular}

pivacaine $\left(5.85 \pm 0.23 \mathrm{ml} \cdot \mathrm{hr}^{-1}\right.$ and $4.59 \pm 0.35 \mathrm{ml} \cdot \mathrm{hr}^{-1}$ for Groups A and B, respectively, $P<0.05$ ) and in Tmax of PPX during hyperthermia $(0.24 \pm 0.03 \mathrm{hr}$ and 0.15 $\pm 0.0 \mathrm{hr}$ for Groups A and B, respectively, $P<0.05$ ).

\section{Discussion}

Our data have shown that hyperthermia induces a decrease in the clearance of bupivacaine and in Tmax of its main metabolite. This may indicate a decreased meta- 
bolic pattern or a reduced renal elimination of the compound during hyperthermia. Thus, one might expect a change in the plasma concentrations of the main metabolite, PPX but this was not confirmed: the only difference observed was a decrease in Tmax indicating a more rapid formation of PPX in hyperthermia-induced animals.

Since the metabolic pathway of bupivacaine involves dealkylation, hydroxylation, amide hydrolysis and conjugation ${ }^{13}$ the decrease of bupivacaine clearance during hyperthermia must be interpreted taking into account similar data which have been observed for other drugs. For instance, Meredith et al. ${ }^{14}$ have shown that influenza vaccination may depress oxidative hepatic metabolism and thus depress theophylline clearance. Matthay et al. ${ }^{10}$ reported in man a decreasing clearance of theophylline during fever, which was considered to be due to a decrease in hepatic drug metabolism and/or renal excretion. Previous studies have shown, for instance, that hydroxylation ${ }^{15}$ and glucuronidation ${ }^{16}$ decrease during fever.

Among the physiological variables known to be changed during fever, ${ }^{\prime}$ plasma proteins may also be concerned in kinetic differences. A decrease in total proteins and albumin concentration has been reported $; 1$ on the contrary, increased binding to acute phase plasma proteins such as fibrinogen or $\alpha$ globulins has been suggested to be responsible for some of kinetic changes. ${ }^{10}$ Yasuhara and Levy ${ }^{17}$ have found lower serum protein concentrations and decreased serum protein binding of theophylline in rats. Since bupivacaine is highly bound to plasma proteins, ${ }^{18}$ one could expect a decreased serum protein binding of this drug and a subsequent increase in the volume of distribution. Our present data do not confirm such an hypothesis but we plan to document this point in further investigations.

In conclusion, the present study, which reports preliminary results, demonstrates a decrease of the plasma clearance of bupivacaine during hyperthermia in rats. Further investigations will perhaps allow us to answer whether the changes are related to fever-induced changes in the protein binding of the drug. These findings may be of interest for practical clinical use of bupivacaine in febrile patients without infection.

\section{Acknowledgement}

The authors would like to thank J. Mouchet for its excellent technical assistance.

\author{
References \\ 1 Ballard BE. Pharmacokinetics and temperature. J Pharm \\ Sci 1974; 63: 1345-58. \\ 2 Lipton A, Hepner GW, White DS, Harvey HA.
}

Decreased hepatic drug demethylation in patients receiving chemo-immunotherapy. Cancer 1978; 41: 1680-4.

3 Stewartforsyth J, Moreland TA, Rylance GW. The effect of fever on antipyrine metabolism in children. Br J Clin Pharmacol 1982; 13: 811-5.

4 Soons PA, Grib C, Breimer DD, Kirch W. Effects of acute febrile infectious diseases on the oral pharmacokinetics and effects of nitrindipine enantiomers and of bisoprolol. Clin Pharmacokinet 1992; 23: 238-48.

5 Kendall MJ, Quarterman CP, Bishop H, Schneider RE. Effects of inflammatory disease on plasma oxprenolol concentrations. B M J 1979; 278: 465-8.

6 Levine $M$, Jones $M W$. Toxic reaction to phenytoin following a viral infection (Letter). Can Med Assoc J 1983; 128 : 1270-1.

7 Fujimura A, Kajiyama, H, Ebihara A. The influence of fever on the pharmacokinetics of pranoprofen in elderly subjects. J Clin Pharmacol 1989; 29: 500-3.

8 Schneider RE, Bishop H, Hawkins CF. Plasma propranolol concentrations and the erythrocyte sedimentation rate. $\mathrm{Br} \mathrm{J}$ Clin Pharmacol 1979; 8: 43-7.

9 Trenholme GM, Williams RL, Rieckmann KH, Frischer $H$, Carson PE. Quinine disposition during malaria and during induced-fever. Clin Pharmacol Ther 1976; 19: 459-67.

10 Matthay RA, Matthay MA, Weinberger MM. Grand mal seizure induced by oral theophylline. Thorax 1976; 31 : 470-1.

11 Björk $M$, Petterson $K J$, Österlöf $G$. Capillary gas chromatographic method for the simultaneous determination of local anaesthetics in plasma samples. J Chromatogr 1990; 533: 229-34.

12 Bruguerolle $B$. Caffeine kinetic changes during the oestrous cycle in rats. Fundam Clin Pharmacol 1992; 6: 45-8.

13 Gohel TJ, Davenport JB, Stanley MJ. Distribution, biotransformation and excretion of bupivacaine in the rat and the monkey. Xenobiotica 1973; 3: 761-72.

14 Meredith $C G$, Christian $C D$, Johnson RF, Troxell $R$, Davis $G L$, Schenker $S$. Effects of influenza virus vaccine on hepatic drug metabolism. Clin Pharmacol Ther 1985; 37: 396-401.

15 Elin RJ, Vesell ES, Wolff SM. Effects of ethiocholanoloneinduced fever on plasma antipyrine half-lives and metabolic clearance. Clin Pharmacol Ther 1975; 17: 447-57.

16 Song CS, Gelb NA, Wolff SM. The influence of pyrogeninduced fever on salicylamide metabolism in man. J Clin Invest 1972; 51: 2959-66.

17 Yasuhara M, Levy G. Kinetics of drug action in disease states XXVI: effect of fever on the pharmacodynamics of theophylline-induced seizures in rats. J Pharmaceut Sci 1988; 77: 569-70.

18 Tucker GT, Mather LE. Clinical pharmacokinetics of local anaesthetics. Clin Pharmacokinet 1979; 4: 241-78. 